\title{
PENERAPAN METODE PEMBELAJARAN INKUIRI UNTUK MENINGKATKAN HASIL BELAJAR IPA TENTANG KEGUNAAN BENDA PLASTIK, KAYU, KACA, DAN KERTAS PADA SISWA TUNANETRA KELAS III DI SLB-A TPA JEMBER
}

\author{
LIS SETYOWATI, S.Pd \\ SLB-A TPA JEMBER
}

\begin{abstract}
Abstrak
Tujuan penelitian ini yaitu: (1) meningkatkan partisipasi belajar IPA melalui metode pembelajaran inkuiri tentang kegunaan benda plastik, kayu, kaca, dan kertas pada siswa kelas III SLB-A TPA Jember; (2) meningkatkan hasil belajar IPA melalui metode pembelajaran inkuiri tentang kegunaan benda plastik, kayu, kaca, dan kertas pada siswa kelas III SLB-A TPA Jember. Subyek penelitian tindakan kelas ini adalah pada mata pelajaran IPA, materi pokok tentang kegunaan benda plastik, kayu, kaca, dan kertas dengan menerapkan metode pembelajaran inkuiri, pada siswa kelas III SLB-A TPA Jember, dengan jumlah 2 siswa. Tempat penelitian tindakan kelas ini adalah di SLB-A TPA Jember, Penelitian ini menggunakan desain penelitian tindakan kelas (PTK). Kesimpulan penelitian ini yaitu: (1) penerapan metode pembelajaran inkuiri dapat meningkatkan partisipasi belajar ipa pada siswa kelas iii di slb-a tpa jember semester ganjil tahun pelajaran 2015/2016 yang ditunjukan dengan peningkatan prosentase partisipasi siswa dari siklus I sebesar $75 \%$ meningkat pada siklus II menjadi $100 \%$, artinya pada siklus ini partisipasi kategori aktif. Jadi, dari siklus I ke siklus II ada peningkatan partisipasi belajar sebesar 25\%; (2) pembelajaran dengan menerapkan metode pembelajaran inkuiri dapat meningkatkan hasil belajar siswa kelas III di SLB-A TPA Jember. Hal ini dapat dilihat pada siklus I, dari 2 siswa yang tuntas sebanyak 1 siswa (50\%) dan yang belum tuntas sebanyak 1 siswa (50\%). Sedangkan pada siklus ii, semua siswa telah tuntas (100\%). Jadi, setelah diadakan siklus ii hasil belajar siswa meningkat sebesar 50\%.
\end{abstract}

Kata kunci: metode pembelajaran inkuiri, hasil belajar, IPA, kegunaan benda plastik, kayu, kaca, dan kertas

\section{PENDAHULUAN}

Setiap kegiatan proses pendidikan diarahkan kepada tercapainya pribadipribadi yang berkembang secara optimal sesuai dengan potensi masing-masing. Pendidikan diwujudkan melalui proses belajar mengajar di dalam kelas maupun di luar kelas. Proses ini berlangsung melalui interaksi antara guru dengan siswa dalam situasi instruksional edukatif .

Dengan adanya pendidikan, seseorang dapat mengembangkan potensi yang ada dalam dirinya sehingga memiliki ilmu, wawasan dan pengetahuan yang luas. Dengan http://doi.org/10.31537/speed.v3i2.279 demikian seluruh warga negara Indonesia baik dalam kondisi normal maupun siswa berkebutuhan khusus berhak mendapatkan pendidikan. Salah satu warga yang berhak memperoleh pendidikan adalah siswa Tunanetra.

Hambatan untuk berfikir kongkrit akan mempengaruhi kemampuan akademis anak tunanetra khususnya pada bidang Ilmu Pengetahuan Alam. Pendidikan IPA di sekolah dasar bermanfaat untuk mempelajari diri sendiri dan alam sekitar. Rizema (2013, hlm. 53) menyatakan bahwa Pendidikan IPA menekankan pada pemberian pengalaman secara langsung untuk mengembangkan kompetensi agar siswa 
mampu menjelajahi dan memahami alam sekitar secara ilmiah. Pelajaran IPA penting untuk dikuasai oleh setiap siswa karena pelajaran IPA dapat mengasah kemampuan dalam memahami dan memecahkan permasalahan IPA dengan kemampuan berpikir. Siswa tunanetra dalam menyelesaikan permasalahan IPA tidak bisa memperoleh secara lengkap dan utuh. Akibatnya perkembangan kognitif siswa tunanetra cenderung terhambat jika dibandingkan pada siswa awas pada umumnya.

Terkait dengan kurikulum SLB-A pada mata pelajaran IPA kelas III semester ganjil tentang Kegunaan Benda Plastik, Kayu, Kaca, dan Kertas, yang apabila hanya dijelaskan secara lisan oleh guru akan menjadi suatu pemahaman yang abstrak bagi siswa tunanetra sehingga perlu untuk mengkongkritkan pemahaman tersebut dalam hal ini perlu adanya metode pembelajaran yang dapat memudahkan aktivitas belajar siswa Tunanetra.

Dalam pelaksanaan pembelajaran IPA ada beberapa hal yang perlu dilaksanakan yang meliputi tahap perencanaan, yakni: pemetaan standar kompetensi yang mencakup penjabaran standar kompetensi dan kompetensi dasar, menentukan tema, identifikasi standar kompetensi, kompetensi dasar dan indikator, menetapkan jaringan tema, penyusunan silabus,silabus adalah rencana pembelajaran pada suatu kelompok mata pelajaran atau tema tertentu yang mencakup standar kompetensi, kompetensi dasar, tema pembelajaran, kegiatan pembelajaran, indikator pencapaian kompetensi untuk penilaian, penilaian, alokasi waktu, dan sumber belajar (Trianto, 2011, hlm. 25). http://doi.org/10.31537/speed.v3i2.279
Kenyataan yang terjadi pada pembelajaran IPA kelas III SLB-A TPA Jember tidak begitu diminati dan kurang disukai siswa. Bahkan siswa beranggapan pembelajaran IPA sulit untuk dipelajari. Akibatnya rata-rata hasil belajar siswa cenderung lebih rendah dibanding mata pelajaran lainnya. Berdasarkan nilai hasil belajar IPA, terungkap bahwa dari 2 siswa kelas III SLB-A TPA Jember, semua memperoleh nilai di bawah KKM (70).

Beberapa faktor yang menyebabkan rendahnya hasil belajar siswa di atas, yaitu: (1) Pembelajaran IPA masih kurang disukai dan kurang diminati siswa bahkan dianggap mata pelajaran yang sulit dipelajari; (2) Dalam pembelajaran IPA tentang Kegunaan Benda Plastik, Kayu, Kaca, dan Kertas, guru masih menggunakan metode ceramah; (3) Guru masih mendominasi pembelajaran tanpa memberi kesempatan kepada siswa berlatih memecahkan masalah; (4) Pembelajaran lebih banyak memaparkan fakta, pengetahuan, hukum kemudian dihafalkan bukan mengaitkan dalam pengalaman empiris dalam kehidupan nyata; (5) Guru masih kurang menggunakan variasi media pembelajaran.

Rendahnya hasil belajar pada pokok bahasan Kegunaan Benda Plastik, Kayu, Kaca, dan Kertas kelas III yang terjadi di SLB-A TPA Jember disebabkan oleh beberapa faktor, seperti: siswa tidak berani bertanya kepada guru tentang materi yang kurang dimengerti karena guru tidak memberi kesempatan untuk 
bertanya, siswa lebih senang bicara sendiri dengan teman sebangku daripada mendengar ceramah dari guru, dan siswa merasa mengantuk saat pemberian materi berlangsung.

Berdasarkan uraian tersebut, maka permasalahan yang dihadapi guru adalah bagaimana menciptakan strategi-metode pembelajaran yang variatif, menyenangkan, dan bermakna sehingga siswa dapat mandiri dan mencapai ketuntasan dalam belajar. Permasalahan inilah yang mendorong penulis untuk memodifikasi berbagai metode pembelajaran sesuai dengan karakteristik materi, karakteristik siswa dan disesuaikan dengan kemampuan guru.

Salah satu strategi yang jarang digunakan dalam pembelajaran IPA adalah Metode pembelajaran Inkuiri. Metode pembelajaran Inkuiri ini kemungkinan dapat mengatasi permasalahan lapangan yang saya dapatkan dari hasil observasi lapangan yang dilaksanakan di SLBA TPA Jember yang diketahui bahwa pada siswa tunanetra kelas III menunjukkan kesulitan memahami pembelajaran IPA dengan metode ceramah yang dilakukan oleh guru. Proses belajar mengajar yang terjadi masih cenderung sebatas ceramah dan pemberian tugas sehingga penguasaan materi tidak bisa diaplikasikan dalam keseharian mereka.

Anak tunanetra perlu berfikir kongkrit bukan abstrak, guru harus memberikan media pembelajaran sesuai dengan materi yang diajarkan, akan tetapi guru hanya menjelaskan http://doi.org/10.31537/speed.v3i2.279 tentang sifat-sifat benda. Akibat dari kurangnya pemahaman dan kreatifitas guru dalam menjelaskan materi dan media pembelajaran, ratarata siswa memperoleh nilai yang cukup rendah, dikarenakan siswa masih tampak kebingungan dan kurang berminat dengan pembelajaran yang diberikan oleh guru, ketrampilan proses siswa dalam proses pembelajaran menjadi sangat kurang, siswa hanya berpedoman pada penjelasan secara lisan oleh guru dan buku saja sebagai alat dan sumber belajarnya,sehingga siswa menjadi sulit untuk memahami tentang apa yang sedang mereka pelajari serta kurangnya kualitas belajar yang mereka miliki dalam memecahkan masalah.

Selanjutnya Sund (dalam Trianto, 2011, hlm. 135) dinyatakan inquiry merupakan perluasan proses discovery yang digunakan lebih mendalam. Inkuiri yang dalam bahasa Inggris inquiry, berarti pernyataan, atau pemeriksaan, penyelidikan. Inkuiri sebagai suatu proses umum yang dilakukan manusia untuk mencari atau memahami informasi.

Menurut Sanjaya (2013, hlm. 196) dinyatakan bahwa metode pembelajaran Inkuiri adalah rangkaian kegiatan pembelajaran yang menekankan pada proses berpikir secara kritis dan analitis untuk mencari dan menemukan sendiri jawaban dari suatu masalah yang dipertanyakan. Metode pembelajaran Inkuiri merupakan bentuk dari pendekatan pembelajaran yang berorientasi kepada siswa. 
Dikatakan demikian,sebab dalam strategi ini siswa memegang peran penting yang sangat dominan dalam proses pembelajaran.

Dari pernyataan di atas strategi inkuiri ini lebih berorientasi kepada siswa dengan memberikan pengalaman-pengalaman belajar yang nyata dan aktif. Hal inilah yang dibutuhkan oleh siswa tunanetra untuk memperbaiki hasil belajar di mata pelajaran IPA tentang Kegunaan Benda Plastik, Kayu, Kaca, dan Kertas maka perlu adanya pengujian strategi tersebut kepada anak tunanetra yang memiliki hambatan berfikir kongkret untuk diterapkan dalam mata pelajaran IPA tentang sifat-sifat benda sehingga apabila strategi tersebut lebih mempengaruhi hasil belajar IPA maka guru dapat mengaplikasikan strategi tersebut kepada siswa tunanetra.

Oleh karena itu, penelitian perbaikan ini sangat penting dilakukan. Penulis memilih judul: "Penerapan Metode Pembelajaran Inkuiri untuk Meningkatkan Hasil Belajar IPA Tentang Kegunaan Benda Plastik, Kayu, Kaca, dan Kertas Pada Siswa Kelas III di SLBA TPA Jember."

Tujuan penelitian ini yaitu untuk meningkatkan partisipasi belajar IPA melalui metode pembelajaran Inkuiri Tentang Kegunaan Benda Plastik, Kayu, Kaca, dan Kertas pada Siswa Kelas III dan meningkatkan hasil belajar IPA melalui metode pembelajaran Inkuiri Tentang Kegunaan Benda
Plastik, Kayu, Kaca, dan Kertas pada Siswa Kelas III SLB-A TPA Jember.

\section{METODE}

Subyek penelitian tindakan kelas ini yaitu pada pembelajaran IPA khususnya Pokok bahasan Kegunaan Benda Plastik, Kayu, Kaca, dan Kertas, pada siswa kelas III SLB-A TPA Jember dengan jumlah 2 siswa, yang bernama Aprillia dan Muhammad Bani Roihan Ainul Yaqin. Pelaku tindakan kelas adalah guru kelas III yang dibantu oleh teman sejawat dan kepala sekolah selama melaksanakan penelitian.

Tempat

penelitian pembelajaran adalah di SLB-A TPA Jember. Adapun waktu penelitian pembelajaran ini dilakukan pada semester Ganjil tahun pelajaran 2015/2016, pada pembelajaran IPA tentang Kegunaan Benda Plastik, Kayu, Kaca, dan Kertas dengan Metode pembelajaran Inkuiri.

Sesuai dengan jenis penelitian yang dipilih, yaitu penelitian tindakan, maka penelitian ini menggunakan model penelitian tindakan dari Kemmis dan Taggart (dalam Arikunto, 2002:83), yaitu berbentuk spiral dari siklus yang satu ke siklus yang berikutnya. Langkah pada siklus berikutnya adalah perencanaan yang sudah direvisi, tindakan, pengamatan, dan refleksi. Sebelum masuk pada siklus 1 dilakukan tindakan pendahuluan yang berupa identifikasi permasalahan.

Untuk menghitung persentase peningkatan hasil belajar siswa 
digunakan dengan teknik sebagai berikut:

$$
H B=\frac{n}{N} \times 100 \%
$$

Keterangan:

HB: persentase hasil belajar

$\mathrm{n}$ : jumlah siswa yang mengalami ketuntasan belajar

$\mathrm{N}$ : jumlah seluruh siswa

Sumber: Nurkanca (1990:93)

Untuk menentukan

peningkatan hasil belajar diperoleh dari perubahan skor hasil belajar pra siklus ke siklus I, siklus II, atau siklus berikutnya.

Tabel 1. Kategori Persentase Hasil Belajar Siswa

\begin{tabular}{|c|c|}
\hline Skor rata-rata & Kategori \\
\hline $\mathrm{P} \geq 90 \%$ & Sangat Baik \\
\hline $80 \% \leq \mathrm{P}<90 \%$ & Baik \\
\hline $65 \% \leq \mathrm{P}<80 \%$ & Cukup Baik \\
\hline $55 \% \leq \mathrm{P}<65 \%$ & Kurang Baik \\
\hline $\mathrm{P}<55 \%$ & Sangat Kurang \\
\hline
\end{tabular}

Sumber: Nurkanca (1990:93)

\section{HASIL DAN PEMBAHASAN}

Data penelitian yang diperoleh berupa data observasi berupa pengamatan pengelolaan pembelajaran menggunakan metode pembelajaran Inkuiri dan data tes formatif siswa pada setiap siklus.

\section{Siklus I}

Pada tahap ini peneliti menyusun perangkat pembelajaran yang terdiri dari RPP I, LKS I, soal tes formatif I, dan alat-alat pembelajaran yang mendukung.

Pelaksanaan kegiatan belajar mengajar untuk siklus I dilaksanakan pada tanggal 06 - 10 Oktober 2015 di kelas III dengan jumlah 2 siswa.
Dalam hal ini peneliti bertindak sebagai guru. Adapun proses belajar mengajar mengacu pada rencana pelajaran yang telah dilakukan. Pengamatan (observasi) dilaksanakan bersamaan dengan pelaksanaan belajar mengajar.

Pada akhir proses belajar mengajar siswa diberi tes/soal dengan tujuan untuk mengetahui tingkat hasil belajar IPA dalam proses belajar mengajar yang telah dilakukan. Berikut ini adalah hasil belajar IPA tentang Pokok bahasan Kegunaan Benda Plastik, Kayu, Kaca, dan Kertas seperti terlihat pada table 2 .

Tabel 2. Hasil Belajar Pokok Bahasan Kegunaan Benda Plastik, Kayu, Kaca, dan Kertas pada Siklus I

\begin{tabular}{|c|l|c|c|c|}
\hline N & \multirow{2}{*}{ Nama Siswa } & \multirow{2}{*}{ Nilai } & \multicolumn{2}{|c|}{ Keterangan } \\
\cline { 4 - 5 } & & 60 & $\mathrm{~T}$ & $\mathrm{Tt}$ \\
\hline 1 & Aprillia & 70 & $\sqrt{ }$ & $\sqrt{ }$ \\
\hline 2 & $\begin{array}{l}\text { M. Bani } \\
\text { Roihan } \\
\text { Jumlah }\end{array}$ & 130 & 1 & 1 \\
\hline \multicolumn{2}{|c|}{$\begin{array}{c}\text { Rata- } \\
\text { Rata/Persentase }\end{array}$} & 65,00 & $50 \%$ & $50 \%$ \\
\hline
\end{tabular}

Dari tabel di atas dapat dijelaskan bahwa dengan menerapkan metode pembelajaran Inkuiri diperoleh nilai rata-rata prestasi belajar siswa adalah 65,00 dan ketuntasan belajar mencapai $50,00 \%$ atau ada 1 siswa dari 2 siswa sudah tuntas belajar. Hasil tersebut menunjukkan bahwa pada siklus pertama secara klasikal siswa belum tuntas 
belajar, karena siswa yang memperoleh nilai $\geq 70$ hanya sebesar 50\% lebih kecil dari persentase ketuntasan yang dikehendaki yaitu sebesar $85 \%$. Hal ini disebabkan karena siswa masih merasa belum mengerti apa yang dimaksudkan dan digunakan guru dengan menerapkan metode pembelajaran Inkuiri.

\begin{tabular}{llr}
\multicolumn{3}{c}{ Pada pertemuan I Siklus } \\
I, pelaksanaan & observasi \\
partisipasi & siswa & dalam \\
pembelajaran & IPA & kelas III
\end{tabular}
tentang Pokok bahasan Kegunaan Benda Plastik, Kayu, Kaca, dan Kertas, terdapat 1 siswa dengan kategori aktif, dan 1 siswa yang pasif sehingga prosentase keaktifan siswa sebesar 50\%. Begitu juga, pada pertemuan II Siklus I, pelaksanaan observasi partisipasi siswa dalam pembelajaran IPA kelas III tentang Pokok bahasan Kegunaan Benda Plastik, Kayu, Kaca, dan Kertas, semua siswa dengan kategori aktif sehingga prosentase keaktifan siswa sebesar $100 \%$. Jadi, rata-rata partisipasi belajar siswa pada siklus I sebesar $\mathbf{7 5 \%}$.

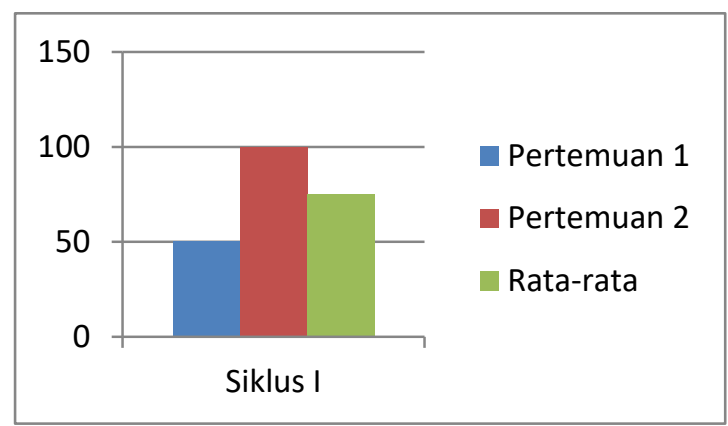

Gambar 1. Rata-rata Partisipasi IPA

http://doi.org/10.31537/speed.v3i2.279

\section{Kelas III Siklus I}

Pada tahap refleksi akan dikaji apa yang telah terlaksana dengan baik maupun yang masih kurang baik dalam proses pembelajaran dengan penerapan metode pembelajaran Inkuiri. Dari data-data yang telah diperoleh dapat duraikan sebagai berikut:

1. Selama proses pembelajaran, dalam penerapan metode pembelajaran Inkuiri ada beberapa aspek yang belum sempurna.

2. Berdasarkan data hasil pengamatan diketahui bahwa siswa masih kurang aktif selama proses belajar berlangsung.

3. Hasil belajar siswa pada siklus I belum mencapai ketuntasan.

4. Partisipasi belajar siswa pada siklus I hanya sebesar 75\%, artinya pada Siklus I ini partisipasi kategori pasif.

\section{Siklus II}

Pada tahap ini peneliti menyusun perangkat pembelajaran yang terdiri dari RPP II, LKS II, soal/tes II, dan media yang mendukung.

Pelaksanaan kegiatan belajar mengajar untuk siklus II dilaksanakan pada tanggal 13 17 Oktober 2015 di kelas III dengan jumlah siswa 2 siswa. Dalam hal ini peneliti bertindak sebagai guru. Adapun proses belajar mengajar mengacu pada Rencana Pelaksanaan Pembelajaran dengan 
memperhatikan revisi pada siklus I, sehingga kesalahan atau kekurangan pada siklus I tidak terulang lagi pada siklus II. Pengamatan dilaksanakan bersamaan dengan pelaksanaan pembelajaran.

Pada akhir proses pembelajaran, siswa diberi tes/soal II dengan tujuan untuk mengetahui tingkat hasil belajar IPA dalam proses pembelajaran yang telah dilakukan. Berikut ini adalah hasil belajar IPA tentang Pokok bahasan Kegunaan Benda Plastik, Kayu, Kaca, dan Kertas pada siklus II, seperti pada tabel 4.2 .

Tabel 3. Hasil Belajar Pokok Bahasan Kegunaan Benda Plastik, Kayu, Kaca, dan Kertas pada Siklus II

\begin{tabular}{|c|c|c|c|c|}
\hline \multirow{2}{*}{$\begin{array}{c}\mathrm{N} \\
\mathrm{o}\end{array}$} & \multirow{2}{*}{$\begin{array}{l}\text { Nama } \\
\text { siswa }\end{array}$} & \multirow[b]{2}{*}{ Nilai } & \multicolumn{2}{|c|}{ Keterangan } \\
\hline & & & $\mathrm{T}$ & $\mathrm{Tt}$ \\
\hline 1 & Aprillia & 80 & $\sqrt{ }$ & - \\
\hline 2 & \begin{tabular}{|l|} 
M. \\
Bani \\
roihan \\
ainul \\
yaqin \\
\end{tabular} & 90 & $\sqrt{ }$ & - \\
\hline \multicolumn{2}{|c|}{ Jumlah } & 170 & 2 & 0 \\
\hline \multicolumn{2}{|c|}{$\begin{array}{c}\text { Rata- } \\
\text { rata/prosent } \\
\text { ase } \\
\end{array}$} & 85,00 & $\begin{array}{c}100 \\
\%\end{array}$ & $0 \%$ \\
\hline
\end{tabular}

Berdasarkan tabel di atas diperoleh nilai rata-rata tes formatif sebesar 85 dan dari 2 siswa semuanya telah tuntas. Maka secara klasikal ketuntasan belajar yang telah tercapai sebesar $\quad 100 \% \quad$ (termasuk kategori tuntas). Hasil pada siklus II ini mengalami peningkatan lebih baik dari siklus I. Adanya peningkatan hasil belajar pada siklus II ini dipengaruhi oleh adanya peningkatan kemampuan guru dalam menerapkan metode pembelajaran Inkuiri sehingga siswa menjadi lebih terbiasa dengan pembelajaran seperti ini sehingga siswa lebih mudah dalam memahami materi yang telah diberikan. Pada siklus II ini ketuntasan secara klasikal telah tercapai, sehingga penelitian ini hanya sampai pada siklus II.

Pada pertemuan I Siklus II, pelaksanaan observasi partisipasi siswa dalam pembelajaran IPA kelas III tentang Pokok bahasan Kegunaan Benda Plastik, Kayu, Kaca, dan Kertas, semua siswa dengan kategori aktif, sehingga prosentase keaktifan siswa sebesar 100\%. Sedangkan, pada pertemuan II Siklus II, pelaksanaan observasi partisipasi siswa dalam pembelajaran IPA kelas III tentang Pokok bahasan Kegunaan Benda Plastik, Kayu, Kaca, dan Kertas, semua siswa juga kategori aktif sehingga prosentase keaktifan siswa sebesar 100\%. Dengan demikian rata-rata partisipasi siswa pada Siklus I sebesar $\mathbf{1 0 0 \%}$. 


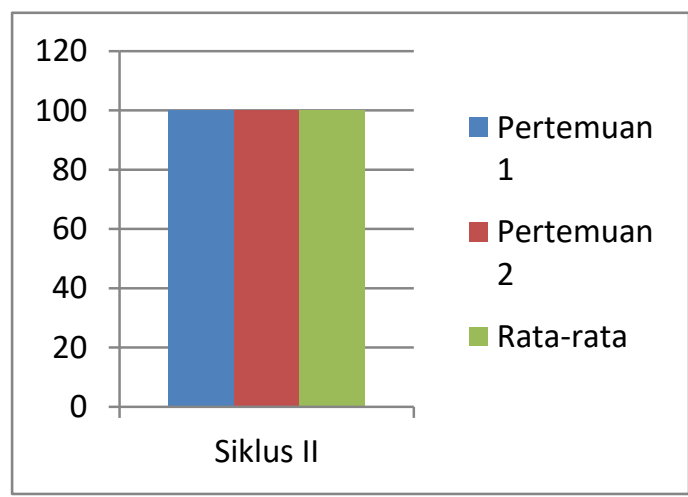

Gambar 4.2. Rata-rata Partisipasi IPA Kelas III Siklus II

Pada tahap refleksi ini akan dikaji apa yang telah terlaksana dengan baik maupun yang masih kurang baik dalam proses pembelajaran dengan penerapan metode pembelajaran Inkuiri. Dari data-data yang telah diperoleh dapat duraikan sebagai berikut:

1. Selama proses pembelajaran, guru telah melaksanakan semua pembelajaran dengan baik. Meskipun ada beberapa aspek yang belum sempurna, tetapi persentase pelaksanaannya untuk masing-masing aspek cukup besar.

2. Berdasarkan data hasil pengamatan diketahui bahwa siswa aktif selama proses belajar berlangsung.

3. Kekurangan pada siklussiklus sebelumnya sudah mengalami perbaikan dan peningkatan sehingga menjadi lebih baik.

4. Hasil belajar siswa pada siklus II mencapai ketuntasan.

5. Partisipasi belajar siswa pada siklus II sebesar $100 \%$, artinya pada Siklus II ini partisipasi kategori aktif.

Pada siklus II guru telah menerapkan metode pembelajaran Inkuiri dengan baik dan dilihat dari hasil belajar siswa pelaksanaan proses pembelajaran sudah berjalan dengan baik. Maka tidak diperlukan revisi terlalu banyak, tetapi yang perlu diperhatikan untuk tindakan selanjutnya adalah memaksimalkan dan mepertahankan apa yang telah ada dengan tujuan agar pada pelaksanaan proses pembelajaran selanjutnya penerapan metode pembelajaran Inkuiri dapat meningkatkan proses pembelajaran sehingga tujuan pembelajaran dapat tercapai.

Melalui hasil peneilitian ini menunjukkan bahwa penerapan metode pembelajaran Inkuiri memiliki dampak positif dalam meningkatkan prestasi belajar siswa. Hal ini dapat dilihat dari semakin mantapnya pemahaman siswa terhadap materi yang disampaikan guru (ketuntasan belajar meningkat dari sklus I, dan II) yaitu masingmasing $\mathbf{5 0 \%}$ dan $\mathbf{1 0 0 \%}$. Pada siklus II ketuntasan belajar siswa secara klasikal telah tercapai. Sedangkan tingkat partisipasi siswa pada pada Siklus I sebesar $\mathbf{7 5 \%}$ kemudian meningkat pada Siklus sebesar $\mathbf{1 0 0 \%}$, artinya pada Siklus II ini partisipasi belajar IPA kategori aktif.

Adapun perbandingan antara kedua Siklus di atas, baik tingkat 
partisipasi maupun hasil belajar dapat dilihat pada tabel berikut ini:

Tabel 4. Perbandingan Partisipasi Belajar IPA Siklus I dan II

\begin{tabular}{|l|c|c|}
\hline \multicolumn{1}{|c|}{ Kategori } & $\begin{array}{c}\text { Rata-rata } \\
\text { Siklus I }\end{array}$ & $\begin{array}{c}\text { Rata-rata } \\
\text { Siklus II }\end{array}$ \\
\hline Aktif & $75 \%$ & $100 \%$ \\
\hline Pasif & $25 \%$ & $0 \%$ \\
\hline $\begin{array}{l}\text { Peningkatan } \\
\text { Partisipasi } \\
\text { Belajar } \\
\text { Siswa }\end{array}$ & \multicolumn{2}{|c|}{$100 \%-75 \%=\mathbf{2 5 \%}$} \\
\hline
\end{tabular}

Tabel 5. Perbandingan Hasil belajar IPA Siklus I dan II

\begin{tabular}{|l|c|c|c|c|}
\hline \multicolumn{1}{|c|}{ Kategori } & \multicolumn{2}{|c|}{$\begin{array}{c}\text { Siklus } \\
\text { I/Prosentase }\end{array}$} & \multicolumn{2}{c|}{$\begin{array}{c}\text { Siklus } \\
\text { II/Prosesentase }\end{array}$} \\
\hline Tuntas & 1 & $50 \%$ & 2 & $100 \%$ \\
\hline $\begin{array}{l}\text { Belum } \\
\text { Tuntas }\end{array}$ & 1 & $50 \%$ & 0 & $0 \%$ \\
\hline $\begin{array}{l}\text { Peningkatan } \\
\text { Hasil } \\
\text { Belajar } \\
\text { Siswa }\end{array}$ & \multicolumn{5}{|c|}{$100 \%-50 \%=\mathbf{5 0 \%}$} \\
\hline
\end{tabular}

\section{PENUTUP}

\section{Simpulan}

Dari hasil kegiatan pembelajaran yang telah dilakukan selama dua siklus, dan berdasarkan seluruh pembahasan serta analisis yang telah dilakukan dapat disimpulkan bahwa:

1. Penerapan metode pembelajaran Inkuiri dapat meningkatkan partisipasi belajar IPA pada siswa kelas III di SLB-A TPA Jember yang ditunjukan dengan peningkatan prosentase partisipasi siswa dari Siklus I sebesar 75\% meningkat pada Siklus II menjadi $100 \%$, artinya pada Siklus ini partisipasi kategori aktif. Jadi, dari Siklus I ke Siklus II ada peningkatan partisipasi belajar sebesar $\mathbf{2 5 \%}$.
2. Pembelajaran dengan menerapkan metode pembelajaran Inkuiri dapat meningkatkan hasil belajar siswa kelas III di SLB-A TPA Jember. Hal ini dapat dilihat pada Siklus I, dari 2 siswa yang tuntas sebanyak 1 siswa (50\%) dan yang belum tuntas sebanyak 1 siswa (50\%). Sedangkan pada Siklus II, semua siswa telah tuntas (100\%). Jadi, setelah diadakan Siklus II hasil belajar siswa meningkat sebesar $\mathbf{5 0 \%}$.

\section{Saran} yang diperoleh dari uraian sebelumnya agar proses pembelajaran IPA lebih efektif dan lebih memberikan hasil yang optimal bagi siswa, maka disampaikan saran sebagai berikut:

1. Untuk melaksanakan metode pembelajaran Inkuiri memerlukan persiapan yang cukup matang, sehingga guru harus mampu menentukan atau memilih topik yang benar-benar bisa diterapkan dalam proses pembelajaran sehingga diperoleh hasil yang optimal.

2. Dalam rangka meningkatkan hasil belajar siswa, guru hendaknya lebih sering melatih siswa dengan berbagai metode pembelajaran, walau 
dalam taraf yang sederhana, dimana siswa nantinya dapat menemukan pengetahuan baru, memperoleh konsep dan keterampilan, sehingga siswa berhasil atau mampu memecahkan masalah-masalah yang dihadapinya.

3. Perlu adanya penelitian yang lebih lanjut, karena hasil penelitian ini hanya dilakukan di SLB-A TPA Jember.

\section{DAFTAR PUSTAKA}

Arikunto, Suharsimi. 2002. Prosedur Penelitian Suatu Pendekatan Praktek. Jakarta: Rineksa Cipta

Depdiknas. 2006. Model Pembelajaran IPA SD. Jakarta: Depdiknas

Depdiknas. 2006. Metode pembelajaran Yang Mengaktifkan Siswa. Jakarta: Depdiknas

Hamalik, Oemar. 2001. Psikologi Belajar dan Mengajar. Bandung: Sinar Baru Algesindo

Mumpuniarti, 2007, Pendekatan Pembelajaran Bagi Anak Hambatan Mental. Yogyakarta: Kanwa Publisher

Rizema, Sitiatava. 2013. Desain Belajar Mengajar Kreatif Berbasis Sains. Jogjakarta: DIVA Press

Roestiyah. 2001. Strategi Belajar Mengajar. Jakarta: Bina Aksara

Sanjaya, Wina. 2013. Strategi Pembelajaran Berorientasi
Standar Proses Pendidikan. Jakarta: Kencana Prenadamedia Grup

Silberman, Melvin. L. 2007. Active Learning. 101 Cara Belajar Siswa Aktif. Bandung: Nuansa dan Nusamedia.

Sudjana, 1990, Teori-teori Belajar Untuk Pengajaran. Bandung: Fakultas. Ekonomi UI

Sukidin, dkk. 2002. Manajemen Penelitian Tindakan Kelas. Surabaya: Insan Cendekia.

Suryosubroto. 2002. Proses Belajar Mengajar di Sekolah. Jakarta: Rineksa Cipta

Trianto. 2011. Model-Model Pembelajaran Inovatif Berorientasi Konstruktvistik. Jakarta: Prestasi Pustaka Publisher

Udin, Syaefudin. 2008. Pembelajaran Terpadu. Bandung: UPI Press. 